\title{
Ten years of change to coral communities off Mona and Desecheo Islands, Puerto Rico, from disease and bleaching
}

\author{
Andrew W. Bruckner ${ }^{1,2, *}$, Ronald L. Hill ${ }^{3}$ \\ ${ }^{1}$ Khaled bin Sultan Living Oceans Foundation, 8181 Professional Place, Suite 215, Landover, Maryland 20785, USA \\ ${ }^{2}$ NOAA Fisheries, Coral Reef Conservation Program, Office of Habitat Conservation, 1315 East West Highway, Silver Spring, \\ Maryland 20910, USA \\ ${ }^{3}$ NOAA Fisheries, Southeast Fisheries Science Center, 4700 Ave. U, Galveston, Texas 77551, USA
}

\begin{abstract}
Remote reefs off southwest Puerto Rico have experienced recent losses in live coral cover of 30 to $80 \%$, primarily due to the decline of Montastraea annularis and M. faveolata from disease and bleaching. These species were formerly the largest, oldest, and most abundant corals on these reefs, constituting over $65 \%$ of the living coral cover and 40 to $80 \%$ of the total number of colonies. From 1998 to 2001, outbreaks of yellow band disease (YBD) and white plague (WP) affected 30 to $60 \%$ of the M. annularis (complex) colonies. Disease prevalence declined beginning in 2002, and then increased immediately following the 2005 mass bleaching event. Colonies of $M$. annularis (complex) have been reduced in abundance by 24 to $32 \%$, and remaining colonies are missing more than half their tissue. Both $M$. annularis and $M$. faveolata have failed to recruit, resheeting has been minimal, and exposed skeletal surfaces are being colonized by macroalgae, bioeroding sponges, and hydrozoans. Other scleractinian corals were smaller in size (mean $=28 \mathrm{~cm}$ diameter) and exhibited lower levels of partial mortality; these taxa were affected to a lesser extent by coral diseases and bleaching-associated tissue loss over the last decade. The numbers of small colonies $(1$ to $9 \mathrm{~cm})$ of these species identified since 2005 also exceeded numbers of larger colonies that died. These reefs appear to be exhibiting shifts in species assemblages, with replacement of $M$. annularis (complex) by shorter-lived brooding species and other massive and plating corals (Agaricia, Porites, Meandrina, Eusmilia, Diploria, and Siderastrea spp.). To avoid a catastrophic and permanent loss of the dominant, slow-growing reef-building corals, the causes and effects of diseases need to be better understood, and possible control mechanisms must be developed. In particular, steps must be taken to mitigate environmental and anthropogenic stressors that increase the spread and severity of disease.
\end{abstract}

KEY WORDS: Coral disease $\cdot$ Bleaching $\cdot$ Coral cover $\cdot$ Montastraea annularis $\cdot$ Loss of coral

\section{INTRODUCTION}

Coral reefs throughout the western Atlantic have experienced widespread reductions in coral cover due to increasing anthropogenic and natural stressors. Diseases are now recognized among the major factors responsible for large declines of living coral cover, biodiversity, and habitat, especially in the Caribbean basin (Green \& Bruckner 2000, Aronson \& Precht 2001, Sutherland et al. 2004, Weil 2004, Bruckner \& Bruckner 2006a, Weil \& Cróquer 2009). The potential for dis- ease to modify benthic coral reef habitats was first observed in the mid-1980s, following the Caribbeanwide massive mortality of the black sea urchin Diadema antillarum. Within months of the die-off, macroalgae, normally grazed by these urchins, began to proliferate and overgrow corals, and in turn, limited the potential for successful settlement and survival of coral planula and recovery of coral populations (Lessios 1988, Carpenter 1990, Hughes 1994, Aronson et al. 2002). An outbreak of white band disease emerged in the US Virgin Islands (USVI) in 1977 and 
spread throughout the Caribbean over a period of about a decade, devastating populations of 2 critical foundation species, Acropora palmata and A. cervicornis (Bruckner 2003). Losses of Caribbean acroporids and concurrent increases in macroalgae have resulted in the disappearance of the classic coral zonation patterns common on most Caribbean reefs until the late 1970s (Aronson \& Precht 2001, Edmunds \& Carpenter 2001).

The most important framework corals remaining on western Atlantic reefs today, Montastraea annularis (species complex) have also begun to exhibit a conspicuous trend of decline throughout the region due to disease, bleaching, predation, and increased competition by other benthic organisms (Bruckner \& Bruckner 2003, 2006a,b, Edmunds \& Elahi 2007). These corals are now known to be susceptible to at least 5 major diseases (Weil 2004, Weil \& Cróquer 2009), and they often show signs of multiple infections simultaneously (Bruckner \& Bruckner 2006a). The prevalence of yellow band disease (YBD) increased dramatically since 1999 on reefs off the western end of Mona Island, and over the next $4 \mathrm{yr}$ it spread throughout the reef system, causing widespread tissue loss to affected $M$. annularis (complex) colonies (Bruckner \& Bruckner 2006a). During the summer of 2005, anomalously warm water temperatures and doldrum-like conditions coincided with a Caribbean-wide mass bleaching event that further compromised these corals. In southwest Puerto Rico, extensive bleaching was associated with recordbreaking sea water temperatures; the bleaching event was compounded by intensive outbreaks of white plague (WP) and YBD, with $M$. annularis colonies losing 50 to $60 \%$ of their live tissue in some locations (Ballantine et al. 2008). Similar bleaching-related mortality and disease outbreaks were noted off eastern Puerto Rico and the USVI during this period (Miller et al. 2006, Ballantine et al. 2008).

The loss of Montastraea annularis (complex) is highly relevant to the persistence of western Atlantic reefs, as these species play a critical role in reef construction and community ecology (Goreau 1959, Knowlton 1992). Their continued existence during periods of increased natural or anthropogenic disturbances will be dependent on both their life history traits and recruitment potential and success (Hughes 1984, 1990). These species form large, long-lived corals that have been dominant on these reefs for millennia (Jackson 1992). They are typically resistant to most physical disturbances, and until recently were thought to be better able to survive periods of adverse conditions than most other species (Johnson et al. 1995). These taxa exhibit numerous characteristics of k-selected species, including low larval recruitment rates, slow growth rates, and development of large colonies with low rates of whole and partial colony mortality as well as moderate regeneration capabilities (Bak \& Engel 1979, Meesters et al. 1996).

Montastraea annularis (complex) colonies can be considered 'bet-hedgers': they live for centuries, require many years before first reproduction, and they exhibit some of the lowest larval recruitment rates reported for reef-building corals (Szmant-Froelich 1985). The historical occurrence of large, hundreds of year old colonies of $M$. annularis (complex) and few colonies less than $30 \mathrm{~cm}$ in diameter suggests that recruitment events of significance have not occurred among these species in several decades, even though large numbers of gametes are produced on an annual basis. Low recruitment rates were probably less important for the survival of $M$. annularis in the past, however, compared to many of the short-lived brooders such as Agaricia and Porites spp. (Hughes \& Tanner 2000) because of their persistence as mature colonies. $M$. annularis generally recovered well from partial mortality caused by most natural disturbances, and they were successful at forming large, monospecific stands through asexual fission and fragmentation.

The recent emergence of new, extremely virulent diseases and mass bleaching events appear to be unsustainable for these taxa, and recovery from these catastrophic and chronic events may take centuries or longer. For example, WP is an extremely virulent coral disease which causes tissue loss at rates of $\geq 1 \mathrm{~cm} \mathrm{~d}^{-1}$, exceeding annual colony growth rates by 10 -fold or more (Gladfelter et al. 1978, Richardson et al. 1998, Bruckner \& Bruckner 2006a,b). YBD progresses much more slowly $\left(1 \mathrm{~cm} \mathrm{mo}^{-1}\right)$, but the disease persists for prolonged periods (up to $8 \mathrm{yr}$ or more), and it typically manifests in multiple locations, exacerbating the extent of tissue mortality (Bruckner \& Bruckner 2006a). Even if these species survive these disease events, partial tissue mortality may cause a regression of colonies to sizes that are below the threshold for successful reproduction (Szmant 1991).

In the present study, factors contributing to longterm changes in coral community structure were examined in 2 offshore locations affected minimally by anthropogenic pollutants and sedimentation. The original hypothesis tested was that changes in rates and extents of coral disease or bleaching could lead to identifiable changes in ecological structure of the reef community. The effects of coral disease and bleaching on the major reef-building corals were followed for 10 to $13 \mathrm{yr}$ within shallow (4 to $25 \mathrm{~m}$ depth) forereef locations off Mona and Desecheo Islands, Puerto Rico. Data on the effects of YBD on Montastraea annularis (complex) at Mona Island between 1996 and 2004 were summarized in a previous study (Bruckner \& Bruckner 2006a); the present study extends that analysis 
through 2008 and broadens the geographic scope. Annual monitoring of permanent stations and additional random transects conducted in 2005, 2006, and 2008 allowed a more detailed assessment of changes in coral cover, species composition, and population demographics for each site, as well as comparisons between offshore (Mona) and nearshore (Desecheo Island) locations. An evaluation of the overall extent of recent losses, the potential for recovery, and some biotic factors affecting the resilience of these communities are also discussed.

\section{MATERIALS AND METHODS}

This study combined belt transects $(1 \times 30 \mathrm{~m})$, permanent radial plots (10 $\mathrm{m}$ radius; $314 \mathrm{~m}^{2}$ area), and tracking of individual colonies tagged between 1995 and 2008 to evaluate changes in coral species composition, cover, size structure, and extent of partial and whole colony mortality resulting from coral diseases and bleaching. The study sites are located off 2 uninhabited islands with minimal turbidity, sedimentation, and anthropogenic nutrient inputs. These islands have been subjected to intense recreational fishing (SCUBA spear fishing, and hook and line) and subsistence/commercial fishing that has depleted predatory fishes and large herbivores (P. Garcia pers. comm.), although por- tions of the islands have recently been protected from fishing.

Between 1995 and 2000, paired radial plots ( $\mathrm{n}=18)$, each $314 \mathrm{~m}^{2}$ in area, were established at randomly selected sites on 6 reefs off Mona Island (Carmelita North, Carmelita South, Mujeres West, Mujeres Wall, Carabinera [1995], and Pajaros [2000]) and 3 reefs off Desecheo Island (Candyland, Puerto de Botes, and Cable Reef [1999]; Fig. 1). Sites ranged in depth from 4 to $25 \mathrm{~m}$ (Table 1). The center of each site was randomly selected by dropping a small flagged fishing weight from a boat at the surface, and permanently marked with an imbedded stainless steel rod. In the initial surveys (1995-1997), all scleractinian corals within each radial plot were counted, recorded to species, and assessed for the presence of disease; no measures of colony size were recorded. Active cases of coral diseases, bleaching, and other signs of recent mortality were recorded annually within each plot (except for 2002), throughout the duration of the study. Total cover of the dominant benthic organisms, recorded to species (for corals) or functional group for other invertebrates (e.g. sponge, gorgonian, or colonial anemone) and algae (filamentous algae, crustose coralline algae, erect coralline algae, and macroalgae), was first determined in 1998 (2000 for Pajaros and 3 sites off Desecheo Island) and reexamined in 2008 using a point intercept method. Cover was estimated from a

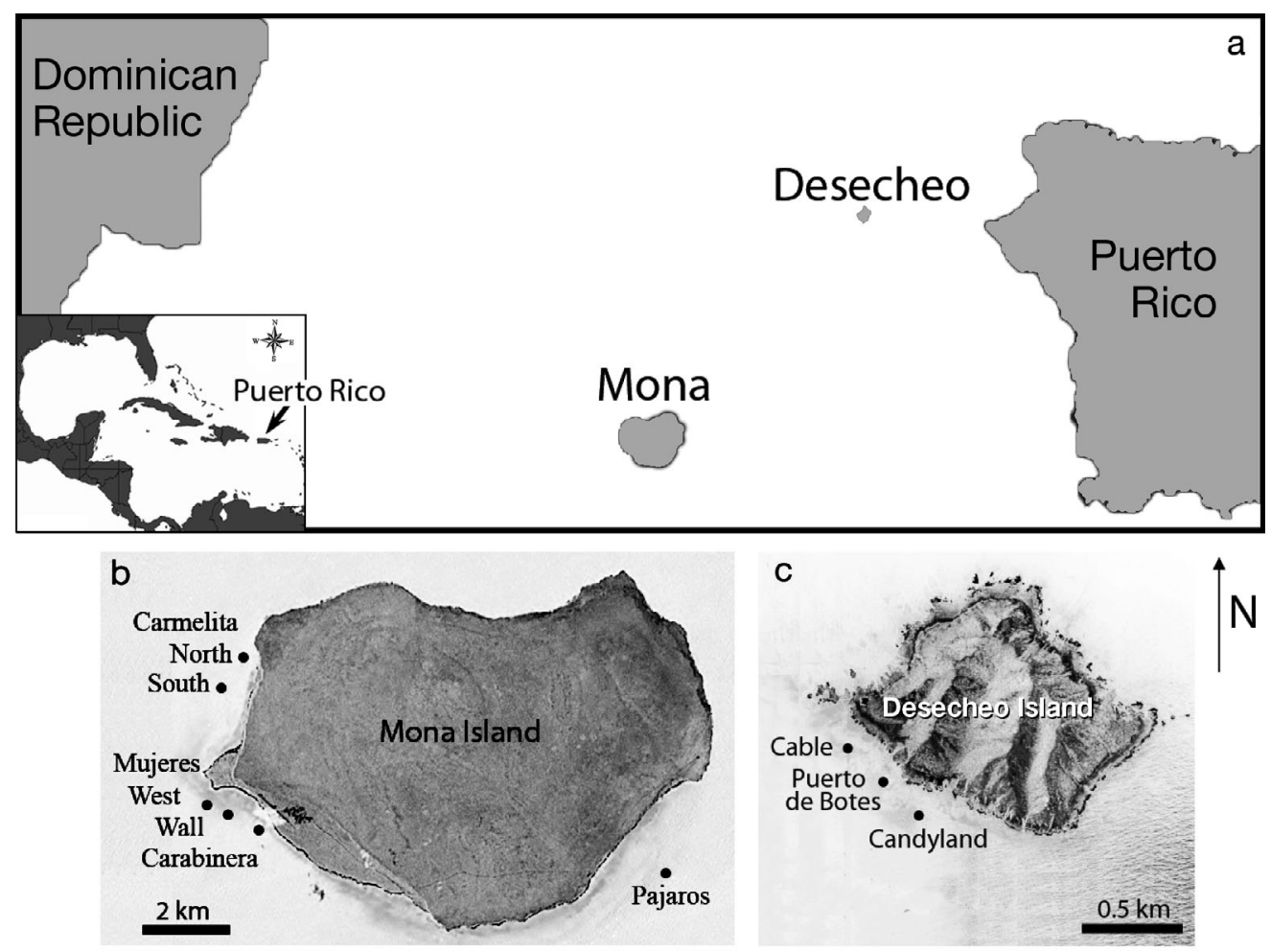

Fig. 1. Study sites examined off Mona Island and Desecheo Island, Puerto Rico. (a) Location of study areas in the western Atlantic and location of permanent sites examined off (b) Mona Island and (c) Desecheo Island 
Table 1. Summary of permanent sites examined off Mona (Carmelitas North and South, Mujeres Wall and West, Carabinera, and Pajaros) and Desecheo (Candyland, Cable, and Puerto de Botes) Islands, Puerto Rico. The total number of colonies and percent loss between first sample date (Mona: 1998; Desecheo: 2000) and 2008 are from two $314 \mathrm{~m}^{2}$ permanent radial plots per site pooled for the 3 species of Montastraea annularis (complex) and for all other species

\begin{tabular}{|c|c|c|c|c|c|c|c|c|c|}
\hline \multirow[t]{2}{*}{ Site } & \multicolumn{2}{|c|}{ Location } & \multirow{2}{*}{$\begin{array}{l}\text { Depth } \\
\text { (m) }\end{array}$} & \multicolumn{3}{|c|}{ No. of M. annularis } & \multicolumn{3}{|c|}{ No. of other spp } \\
\hline & ${ }^{\circ}$ North & ${ }^{\circ}$ West & & $1998 / 2000$ & 2008 & $\%$ loss & $1998 / 2000$ & 2008 & $\%$ loss \\
\hline Carmelita N & 18.10334 & 67.93641 & $5-10$ & 175 & 126 & 28 & 442 & 439 & 0.7 \\
\hline Carmelita S & 18.09964 & 67.93825 & $8-12$ & 67 & 49 & 27 & 232 & 222 & 4.3 \\
\hline Mujeres Wall & 18.07243 & 67.94310 & $18-22$ & 191 & 139 & 26 & 333 & 330 & 0.7 \\
\hline Mujeres West & 18.07300 & 67.94220 & $16-21$ & 193 & 156 & 19 & 294 & 270 & 8.2 \\
\hline Carabinera & 18.07194 & 67.93948 & $20-25$ & 83 & 52 & 37 & 161 & 152 & 5.7 \\
\hline Pajaros & 18.05493 & 67.85987 & $18-22$ & 114 & 105 & 4 & 267 & 264 & 1.0 \\
\hline Mona all & & & & 823 & 627 & 24 & 1729 & 1678 & 3.0 \\
\hline Candyland & 18.37920 & 67.48386 & $18-23$ & 196 & 134 & 32 & 546 & 539 & 1.0 \\
\hline Cable & 18.38208 & 67.48818 & $7-15$ & 87 & 69 & 21 & 232 & 229 & 1.4 \\
\hline Puerto de Botes & 18.38089 & 67.48671 & $5-18$ & 247 & 157 & 37 & 187 & 183 & 1.8 \\
\hline Desecheo all & & & & 530 & 359 & 32 & 965 & 951 & 1.5 \\
\hline
\end{tabular}

minimum of four $30 \mathrm{~m}$ transects per site, with observations taken every $0.5 \mathrm{~m}$ (60 points per transect). Transects were extended from the center rod $\mathrm{N}, \mathrm{S}, \mathrm{E}$, and $\mathrm{W}$, with additional random transects conducted in surrounding areas.

Detailed assessments of coral demographics and condition were first conducted in 1998-1999 (Mona Island sites) and in 2000 (Desecheo Island sites) and repeated in 2008 (all sites) using a modified Atlantic and Gulf Rapid Reef Assessment (AGRRA) protocol (Kramer \& Lang 2003). Some of the modifications of this method included an assessment of the size structure of all corals $\geq 10 \mathrm{~cm}$ in diameter within permanent radial plots $\left(314 \mathrm{~m}^{2}\right)$, instead of recording observations only along $10 \mathrm{~m}$ transects. For each coral $\geq 10 \mathrm{~cm}$ in diameter, data were collected on (1) species and size, including maximum diameter, width (perpendicular to diameter), and height measured with a $1 \mathrm{~m}$ bar divided into $1 \mathrm{~cm}$ increments, (2) percent of recent and old partial mortality estimated visually for the entire surface of the corallum, (3) causes of recent mortality, if any, recorded as a particular disease, invertebrate or fish predation, algal competition, overgrowth by encrusting invertebrates, or other factor.

The major diseases were identified according to criteria listed for western Atlantic corals in Raymundo et al. (2008). In December 2005, the prevalence and severity of bleaching were evaluated in permanent sites and additional random locations around Mona and Desecheo $(\mathrm{n}=13)$ using belt transects $(30 \times 1 \mathrm{~m})$. Colonies were identified to species, measured, and categorized according to a numeric scale of bleaching severity (ranked from 1 to 5). Colonies were identified as being normal (1), pale (2), patchy bleaching (3), mostly bleached (4), and fully bleached (5), and the color patterns were recorded. In addition, irregular patches of tissue loss initiating within the colony surface (focal lesions) or at the colony margin, adjacent to or within bleached or pale tissue, were identified as bleaching-associated mortality. Although bleaching is a disease, these are often considered separate (but linked) stressors. In this study, the signs and effects of diseases presumed to be microbial in cause (WP and YBD) were very different from bleaching effects. For example, the pattern of tissue loss from bleaching did not progress in a band-like, linear, or radial manner, characteristic of other common western Atlantic diseases; affected tissue was discolored (pale or white), but not in a regular pattern like that observed in YBD (e.g. annular or linear band or round blotch), and there was an absence of a microbial mat. Lesions associated with bleaching also expanded outward in an irregular, random manner, and small patches of tissue could be observed sloughing off the skeleton at the lesion border. For this reason, bleaching and disease were separated when evaluating overall prevalence and effects. Prevalence rates are defined as the total number of corals with active infections observed during a single survey, divided by the total number of corals. Disease incidence refers to the number of new infections observed within a site divided by the total number of corals at that site.

A single colony was defined as the original skeletal surface and the sum of all tissue remnants; individual tissue remnants were not recorded as separate colonies. For lobate colonies of Montastraea annularis, a single colony was defined as the total of all lobes (ramets) joined by a single skeleton (genet). When assessing disease prevalence or incidence in these corals, multiple lesions within a single genet were only counted once (e.g. individual genets were observed with 1 to 27 distinct lesions; these were counted as 1 diseased 
coral). While some differences in disease prevalence and susceptibility to bleaching were noted among $M$. faveolata, M. annularis, and M. franksi, all data presented in this paper, unless specifically indicated, are pooled (M. annularis complex) for simplification. Total numbers of juvenile and sub-adult corals $(1-9 \mathrm{~cm})$ were also recorded for each scleractinian coral species capable of attaining a diameter of $\geq 10 \mathrm{~cm}$ within each belt transect $(30 \times 1 \mathrm{~m})$ conducted in 2008 , and also on the surface of tagged colonies of $M$. annularis (complex) that had been identified with YBD between 1995 and 2001. For purposes of this study, species that achieve a minimum diameter of $10 \mathrm{~cm}$ were defined as 'reef-building' corals. Taxa not evaluated include Scolymia, Manicina, Oculina, Favia, other solitary or ahermatypic corals, and hydrozoan corals. All size and mortality data presented here were collected by A. W. Bruckner to minimize observer variability.

Size structure of corals when the sites were first established (1998-2000) were compared to the size in 2008 for (1) all living corals, (2) corals that lost $>80 \%$ of their tissue, and (3) dead corals. Changes in size were assessed using (1) the maximum diameter, or (2) an estimate of the surface area of the corallum that could be potentially covered by live tissue, determined from the diameter, width, and height $(\mathrm{L} \times \mathrm{W} \times \mathrm{H})$ of the original skeleton (for planar surface area). Tissue loss was estimated visually as a percent of the original planar surface area of the corallum; the area of the colony was multiplied by the percent of living tissue to determine the total amount of remaining live tissue. Comparisons between locations were made using a Student's $t$-test and/or analysis of variance (ANOVA). A Student's $t$ test was used to examine differences in size structure between Montastraea annularis (complex) and between other coral taxa (all species pooled) in 1998 and 2008, and between Mona and Desecheo. Single or multifactorial ANOVA was used for comparisons among multiple locations and years, and differences in coral composition, cover, and percent partial mortality between reefs and years. A regression analysis was undertaken to evaluate relationships between colony size and mortality. Log-transformation for length measurements and arcsine transformation for percentages were used as necessary prior to analyses to normalize data.

\section{RESULTS}

\section{Species composition}

Forereef communities off Mona Island and Desecheo Island contained up to 23 scleractinian coral species (range $=14-23)$. Overall, 13 dominant species ac- counted for more than $90 \%$ of the total number of colonies. Montastraea annularis (complex) was the most abundant taxon at all sites, making up $39 \%$ of all colonies (10 cm diameter or larger) overall, and up to $70 \%$ in selected sites (Fig. 2). No species extirpations were noted at any site over $10 \mathrm{yr}$, although the density and abundance of individual taxa varied between time points, and 3 stands of branching corals (Acropora cervicornis, Madracis mirabilis, and Porites porites) adjacent to permanent sites were destroyed by Hurricane Georges (1998). Both M. faveolata (36\% and $48 \%$ reduction in colony numbers, respectively) and $M$. annularis (19\% and $20 \%$ reduction) sustained the largest losses, and these corals now make up $<20 \%$ $(16 \%$ and $19 \%)$ of all corals off Mona Island and Desecheo Island (respectively). With the exception of Colpophyllia natans, which sustained a $12 \%$ loss at Mona Island, all other species showed minimal

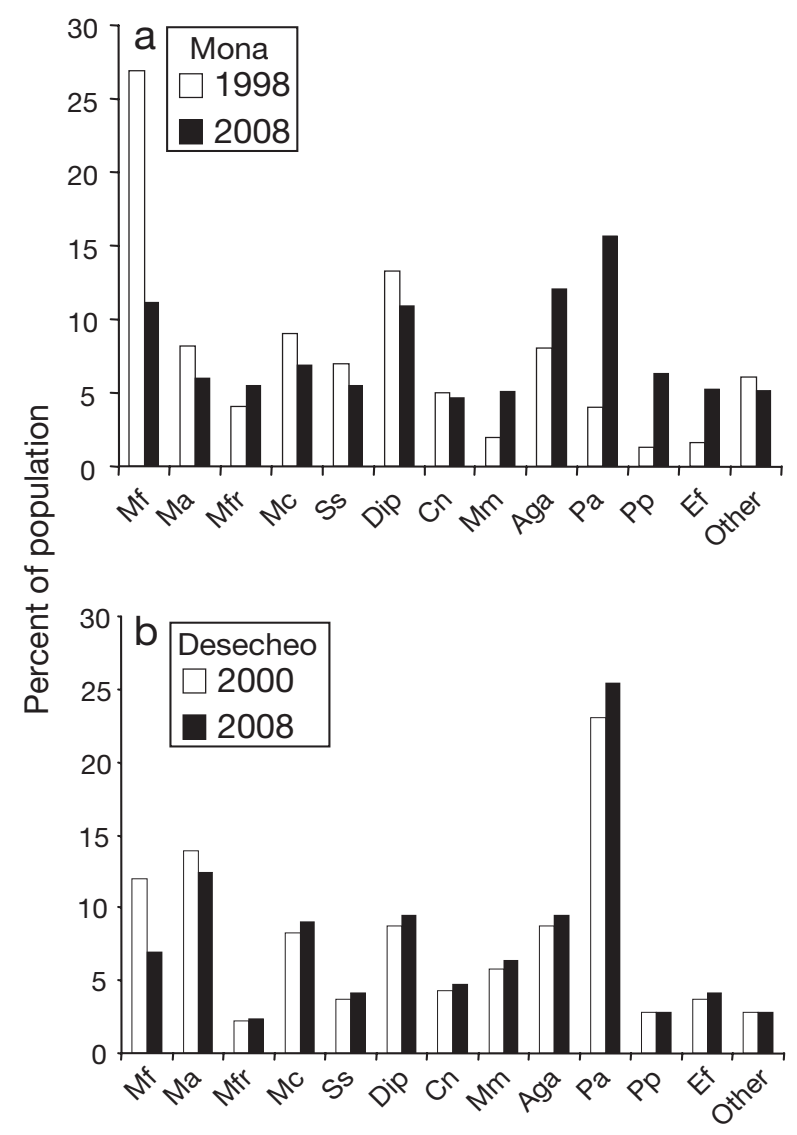

Fig. 2. Abundance of the major taxa of reef-building corals off (a) Mona Island and (b) Desecheo Island in 1998/2000 (white bars) and in 2008 (black bars). Dominant species include Montastraea faveolata (Mf), M. annularis (Ma), M. franksi (Mfr), M. cavernosa (Mc), Siderastrea siderea (Ss), Diploria spp. (Dip), Colpophyllia natans (Cn), Meandrina meandrites $(\mathrm{Mm})$, Agaricia spp. (Aga), Porites astreoides $(\mathrm{Pa})$, P. porites (Pp), and Eusmilia fastigiata (Ef), with up to 9 additional species 
declines or slight increases, with a net reduction of colonies $10 \mathrm{~cm}$ or larger in diameter (all species except M. annularis complex pooled) of $3 \%$ at Mona and $1.5 \%$ at Desecheo (Table 1, Fig. 2).

\section{Coral cover}

The percent cover of corals declined significantly over the duration of the study at all sites from $49 \pm$ $17.5 \%$ (mean $\pm 1 \mathrm{SE}$ ) to $18.8 \pm 5.6 \%$ in 2008 (Fig. 3). Montastraea annularis (complex) covered more of the benthos than any other coral taxon in 1998, with a mean cover at all sites off Mona of $32 \pm 15 \%$. Cover of M. annularis (complex) was higher on reefs off Desecheo Island $(47 \pm 19 \%)$ at the beginning of the study, but these differences were not significant ( $t$-test, $t=1.75, \mathrm{p}=0.11$ ) due to considerable variation between permanent sites. In 2008, remaining live cover of $M$. annularis (complex) ranged from 0 to $14 \%$, with significantly larger declines off Desecheo Island (95\%

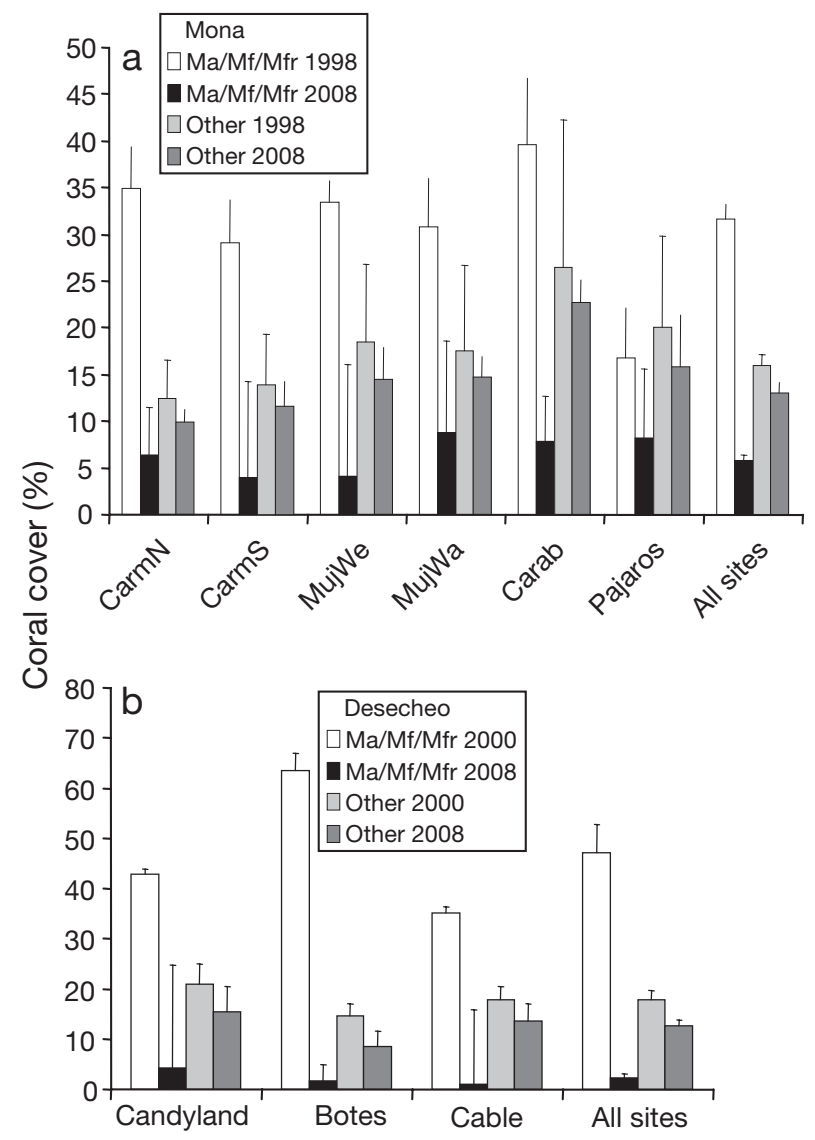

Fig. 3. Percent of living coral cover within (a) 6 permanent sites off Mona and (b) 3 sites off Desecheo Island shown for Montastraea annularis (complex) in 1998/2000 (white bar) and 2008 (black bar) and for other species (pooled) in 1998/2000 (light grey bars) and 2008 (dark grey bars). Ma, Mf, Mfr: for abbreviations see Fig. 2 loss of live $M$. annularis cover versus $78 \%$ decline off Mona Island; $t=3.26, \mathrm{p}=0.01$ ). One site off Mona (Pajaros) that had the lowest cover of $M$. annularis (complex) in 2000 (mean $=16.5 \pm 9.5 \%$ ), sustained the lowest amount of mortality overall (47\% reduction of M. annularis [complex] cover between 2000 and 2008). All other species (pooled) showed small, non-significant declines in cover ( $t$-test, $t=1.7, \mathrm{p}=0.06$ ) between 2000 and 2008 (mean loss $=3.6 \pm 3.7 \%$ ), and certain taxa (e.g. Diploria, Porites, and Agaricia) exhibited minor increases in living cover within some sites.

\section{Population demographics}

Large changes in the size frequency distribution and extent of partial mortality were observed among Montastraea annularis (complex) populations between 1998 and 2008, while the size structure of other taxa was similar at the beginning and end of the study. Although both small $(<20 \mathrm{~cm}$ diameter $)$ and large $(>100 \mathrm{~cm}$ ) colonies of $M$. annularis (complex) were measured during all surveys, there were significant differences in sizes of colonies that were live (mean = $62 \mathrm{~cm}$ diameter), nearly dead (80-99\% partial mortality, mean $=118 \mathrm{~cm}$ ), and completely dead (mean = $92 \mathrm{~cm}$; ANOVA, $F=17.9, \mathrm{p}<0.001)$. The total planar surface area of living tissue on skeletal surfaces of surviving colonies also showed significant declines compared to that observed in 1998 or $2000(t=7.5, \mathrm{p}<0.01)$ due to partial mortality affecting medium and large colonies (mean loss $=55 \pm 2.19 \%$ ) and an increase in the number of colonies with small $(<10 \mathrm{~cm}$ diameter) tissue remnants (Fig. 4). The extent of partial mortality was correlated with size for $M$. annularis (complex) $\left(\mathrm{r}^{2}=0.45-0.56, \mathrm{p}<0.001\right)$, but not for other species $\left(\mathrm{r}^{2}=\right.$ 0.09-0.1, p >0.1; Fig. 5). All other species (pooled species $>9 \mathrm{~cm}$ diameter) exhibited minor, non-significant changes in size structure $($ mean $=28.8 \mathrm{~cm}$ diameter in 2000 versus $28.4 \mathrm{~cm}$ in $2008, t=1.64, \mathrm{p}=0.7$ ), although there was an increase in the number of juveniles in the smallest measured size classes $(1-9 \mathrm{~cm})$. At sites off Mona, these species had a much lower percentage partial mortality $(16.8 \pm 1.0 \%)$ than $M$. annularis (complex), with similar values recorded a decade earlier. The percent partial mortality for surviving colonies of M. annularis complex (mean $=59 \pm 2.9 \%$ ) and other species $(26 \pm 1.9 \%)$ was slightly higher off Desecheo Island in 2008 (Fig. 5b).

\section{Biotic stressors}

The main factors contributing to partial and whole colony mortality were outbreaks of YBD (Fig. 6a,b) and 
WP (Fig. 6c,d), and bleaching-associated mortality in 2005/2006. Other diseases (e.g. black band disease [BBD], dark spots disease, white band disease), previous bleaching events $(1995,1998)$, gastropod and fish corallivory, damselfish algal lawns, and overgrowth of
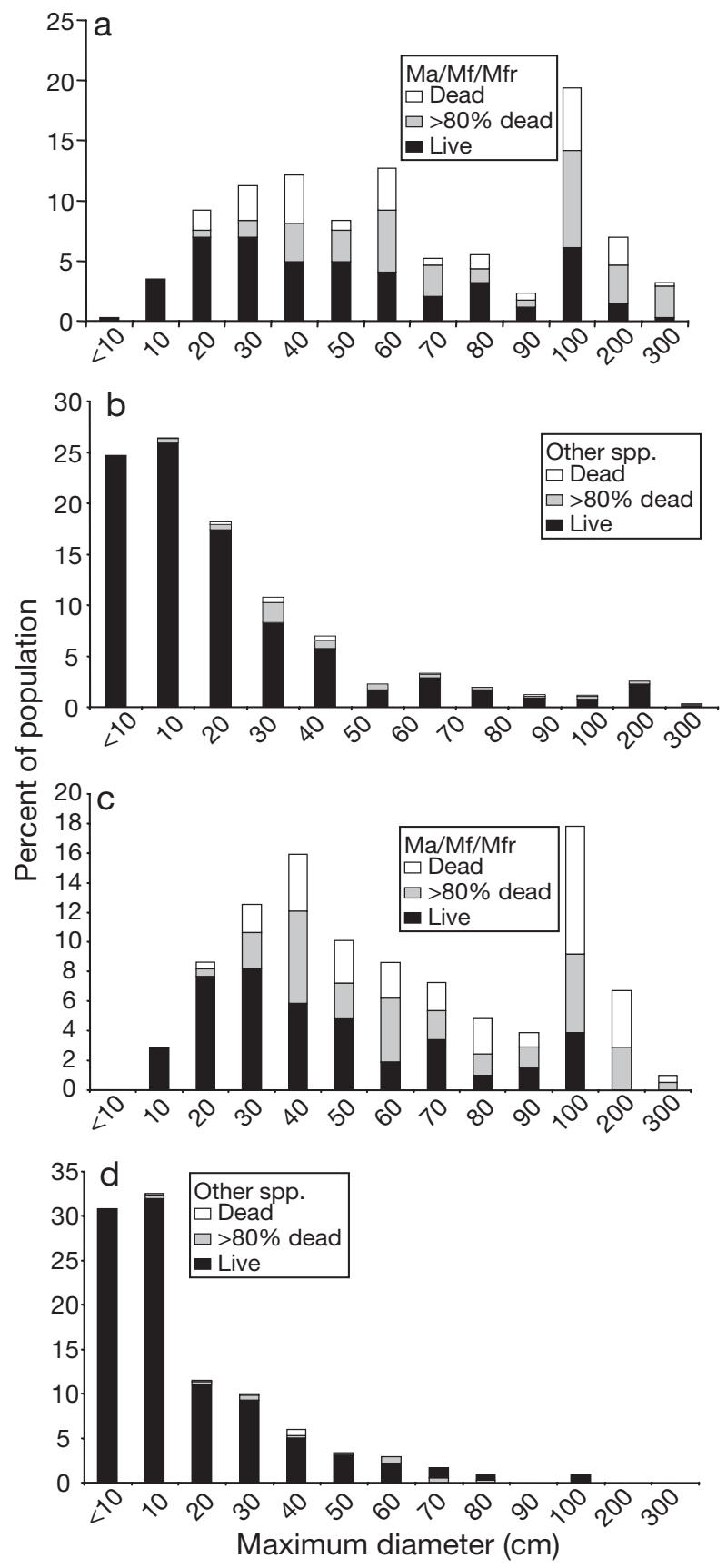

Fig. 4. Change in the size structure of corals on $(a, b)$ Mona Island and (c,d) Desecheo Island reefs (all sites pooled). Each stacked bar illustrates the total percent of the population in a particular size class (maximum diameter) divided into live corals (black bars), corals that were nearly dead (grey bars), and completely dead corals (white bars) for $(\mathrm{a}, \mathrm{c})$ Montastraea annularis (complex; for abbreviations see Fig. 2) and (b,d) other corals (pooled species)

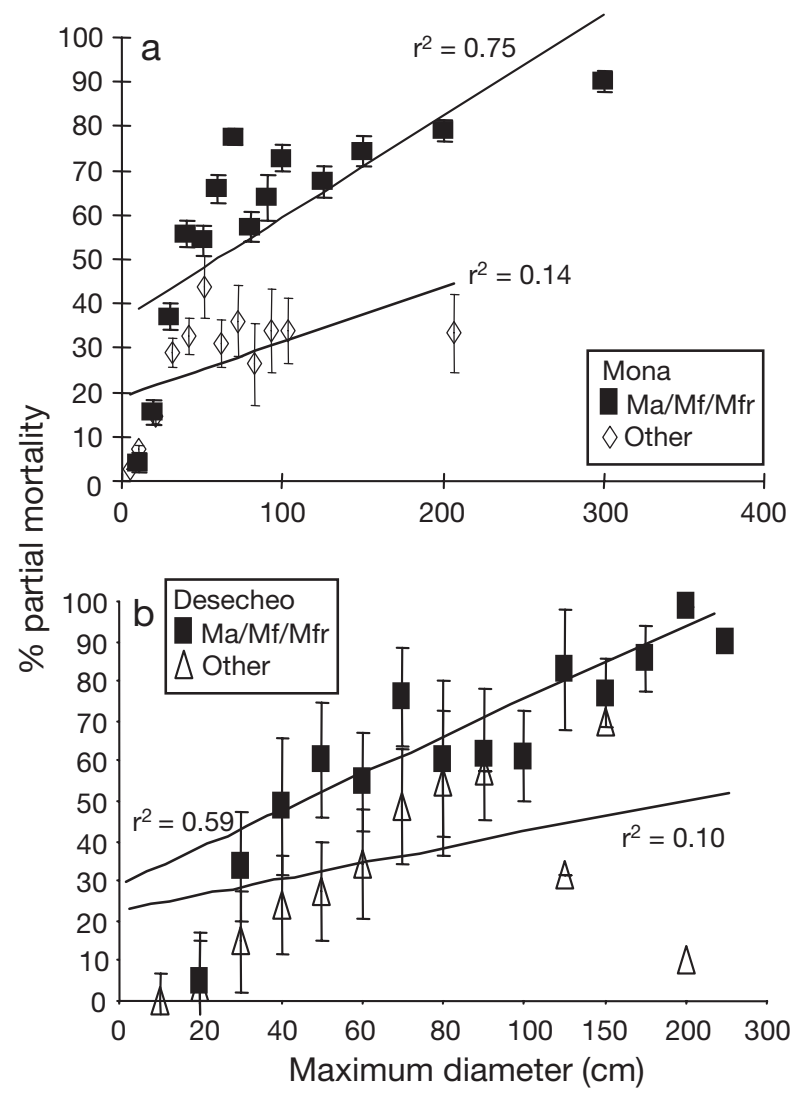

Fig. 5. Relationship between size (maximum diameter) and extent of partial mortality for Montastraea annularis (complex; for abbbreviations see Fig. 2) (black squares) and other species (white diamonds or triangles) in 2008 divided into 14 size classes at (a) Mona Island and (b) Desecheo Island

corals by competitive sponges, hydrozoans, gorgonians, tunicates, and macroalgae were present but uncommon $(<1 \%$ of all corals), except for isolated outbreaks of BBD (Fig. 6e,f) and seasonal blooms of macroalgae and cyanobacteria.

Chronic YBD infections caused extensive tissue loss to Montastraea annularis and M. faveolata. This disease was first documented in 1996 off the northwestern end of Mona Island (Carmelita), and in 1999 off Desecheo Island (Candyland), with up to $52 \%$ of all colonies in a single site showing active signs of YBD at 1 time. The incidence of YBD (number of new infections) increased within individual sites for up to $3 \mathrm{yr}$ after it first emerged, and YBD infections progressively spread to neighboring reefs. While YBD incidence declined between 2001 and 2005, affected colonies showed signs of YBD for 5 to $8 \mathrm{yr}$, and new centers of infection continued to appear on these colonies, until most or all of their tissue was eliminated. A second outbreak of YBD began in December 2005, as colonies began recovering from the 2005 bleaching event (Fig. 6a,b). In addition to a reappearance of YBD on 

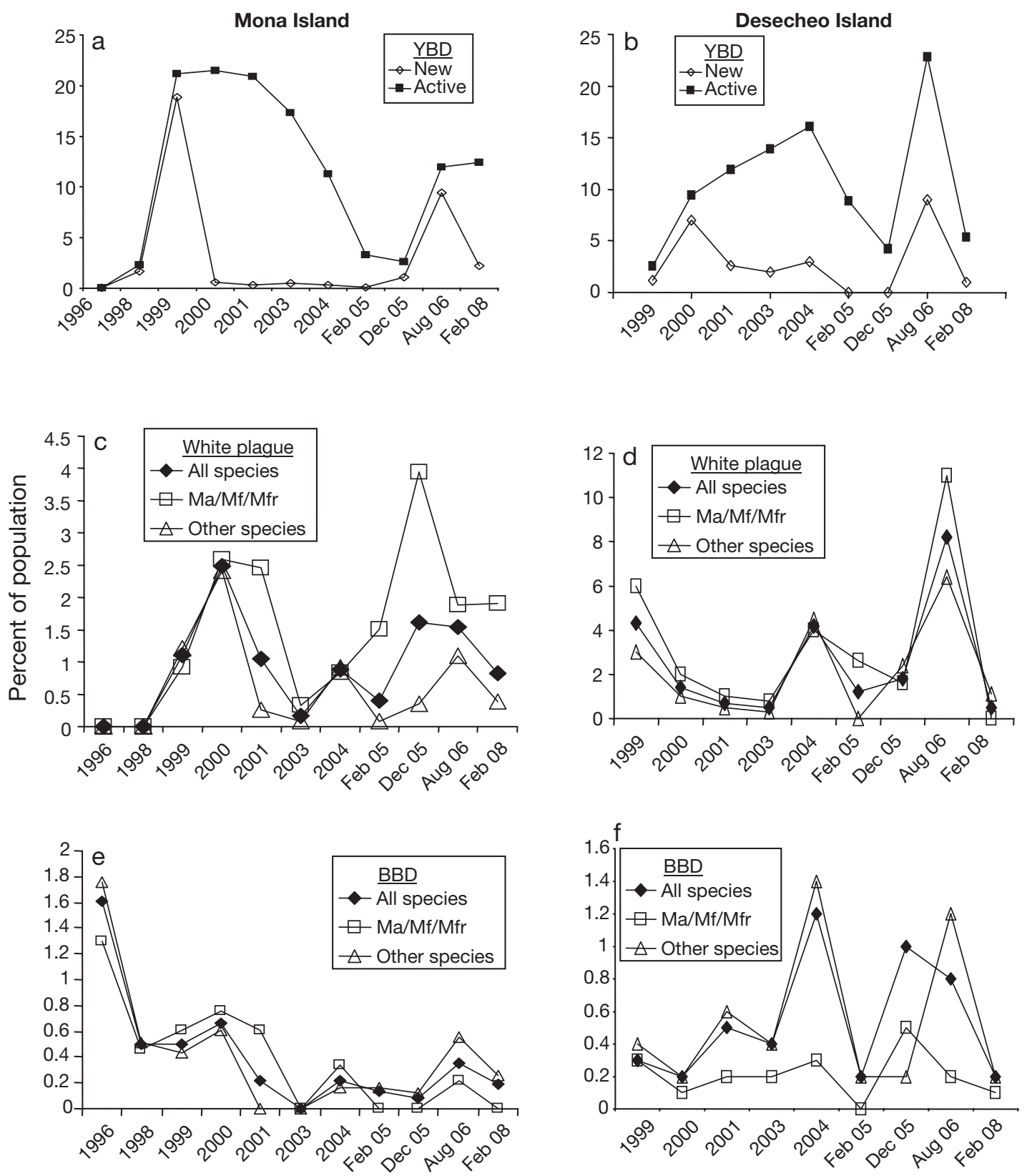

Fig. 6. Percent of the population affected by diseases from 1996 to Feb 2008 for reefs off Mona Island (left) and Desecheo Island (right). (a,b) Prevalence (active infections, black squares) and incidence (new infections, open diamonds) of yellow band disease (YBD) for colonies of Montastraea annularis (complex; for abbreviations see Fig. 2). (c,d) Prevalence of white plague (WP) among all species (black diamonds), M. annularis complex (open squares), and other species (open triangles). (e,f) Prevalence of black band disease (BBD). Symbols as shown for WP

colonies in remission, the largest number of new cases occurred at Pajaros, a site at the eastern end of Mona that remained relatively free of disease until 2005 (Fig. 7).

WP emerged on these reefs in 1999. A total of 21 species of corals have been affected, with the highest prevalence recorded on Montastraea annularis (complex), followed by Diploria, Dichocoenia, and Colpophyllia spp. Although low levels of WP were noted during most surveys since 2000, WP prevalence was highest during 2004, and immediately following the 2005 bleaching event (Fig. 6c,d). Surviving $M$. annularis and $M$. faveolata colonies were affected most severely, with prevalence rates of up to $12 \%$ (Fig. 6c,d).

Mass bleaching was observed in Mona sites during 1995, 1998, and 2005, and during 1998 and 2005 in Desecheo (no data for 1995). There was little direct 


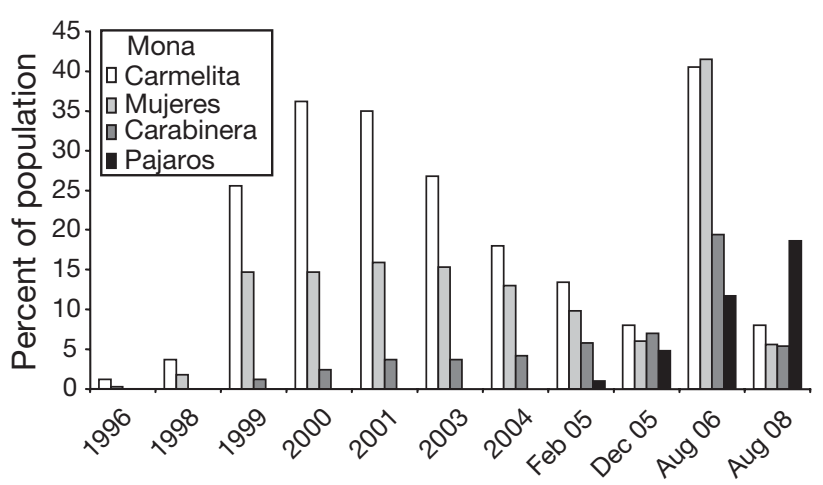

Fig. 7. Montastraea annularis (complex). Patterns of spread of YBD throughout Mona Island reefs. Data are pooled for all sites off Carmelita (white bars), Mujeres (light grey bars),

Carabinera (dark grey bars), and Pajaros (black bars)

mortality associated with the 1995 and 1998 events, and corals appeared normal during post-bleaching surveys in August 1996 and May 1999. In 2005, extensive bleaching was observed following $10 \mathrm{wk}$ of higher than normal water temperatures $\left(30-32^{\circ} \mathrm{C}\right)$. In December 2005, 58\% of all corals at Mona sites and 53\% at Desecheo were still mostly or fully bleached (Fig. 8). The severity of bleaching (ranked from 1 to 5) was correlated with size $\left(\mathrm{r}^{2}=0.42\right)$, with no bleaching ( $\mathrm{rank}=$ 1) observed in most small colonies $(<20 \mathrm{~cm})$ at Mona $(66 \%)$ and Desecheo (73\%), and most larger colonies (>50 cm; 92\% and 96\%, respectively) were fully bleached (Fig. 8c). Some differences in susceptibility were also observed among taxa (Fig. 8d), with a high degree of resistance observed in Porites astreoides (87\%), Stephanocoenia intersepta (81\%), Eusmilia fastigiata (74\%), Meandrina meandrites (66\%), and Dendrogyra cylindricus (64\%), while normal, fully pigmented colonies of Montastraea annularis (complex) were rarely $(<5 \%)$ observed; colonies were mostly bleached (58\%; white to very light yellow), although many $(38 \%)$ had begun to regain coloration (light brown patches or edges).

A number of bleached colonies (10 to $40 \%$, depending on species), including corals that had begun regaining coloration, began exhibiting irregular patches of tissue loss by December 2005. Progressive tissue loss was still ongoing in August 2006, especially among Montastraea faveolata. During these surveys, extensive tissue loss was documented that had occurred over the previous 6 mo, which was attributed to both bleaching and disease. Separating the overall loss of tissue from disease versus bleaching was not possible using the methods applied in this study, mainly because each survey represents a single point in time. These surveys allow an assessment of the total amount of recent mortality at the time of the survey, and whether it is due to disease or bleaching, but not the
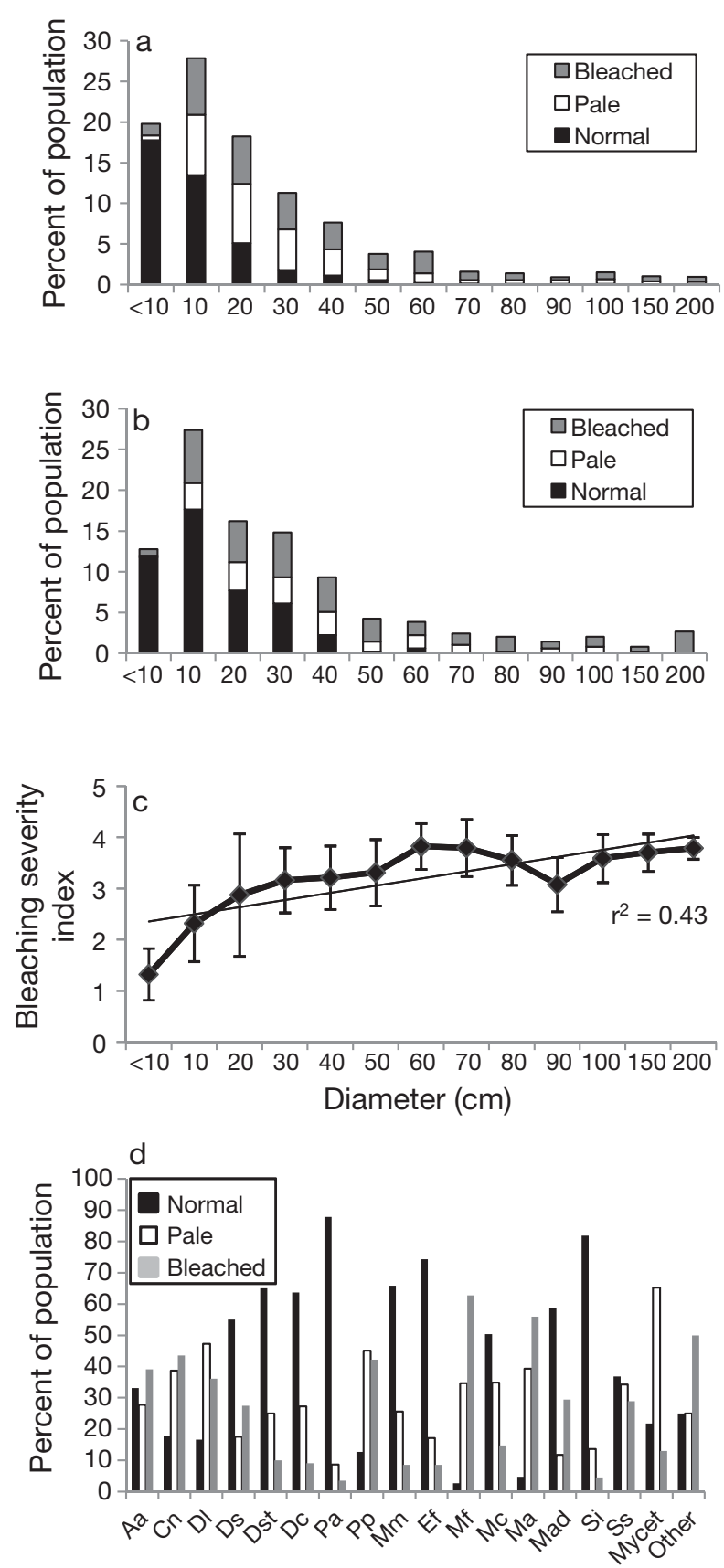

Fig. 8. Extent of bleaching on reefs off Mona and Desecheo Islands in 2005. Total percent of colonies (pooled species) that were not bleached (black bars), pale or mottled (white bars), and fully bleached (grey bars) separated into 13 size classes for (a) Mona and (b) Desecheo. (c) Bleaching severity on a scale of 1 to 5 for each of 13 size classes, where $1=$ normal coloration and $5=$ fully bleached (white; mean $\pm 1 \mathrm{SE}$ ). (d) Total percent of colonies that were unbleached (black bars), pale (white bars) and bleached (grey bars) for the 17 dominant genera and 9 other species (other). Cn, $\mathrm{Pa}, \mathrm{Pp}, \mathrm{Ef}, \mathrm{Mf}, \mathrm{Mc}, \mathrm{Ma}$, Ss: as in Fig. 2. Aa: Agaricia agaricites; Dl: Diploria labyrinthiformis; Ds: Diploria strigosa; Dst: Dichocoenia stokesii; Dc: Dendrogyra cylindricus; Mm: Meandrina meandrites; Mad: Madracis spp.; Si: Stephanocoenia intersepta; Mycet: Mycetophyllia spp. 
amount caused by disease versus bleaching over the duration of the tissue loss event (approximately 6 mo) without examining sites more frequently (e.g. weekly to monthly). In tagged colonies, however, the overall extent of tissue loss from a particular disease can be estimated during periods without major bleaching events if the disease remains active between survey periods.

\section{Patterns of recovery}

As many of the larger, older colonies of Montastraea annularis (complex) continued to shrink in size, new substrata became available for colonization. Much of the available space was occupied by macroalgae (mean $=26.8 \%$ cover, mostly Dictyota and Lobophora spp.) and sponges (mean $=7.2 \%$ cover, up to $30 \%$ at individual sites; mostly Cliona spp. off Mona and Neofibularia spp. off Desecheo) in 2008. These sponges appear to be inhibiting resheeting of tissue remnants over exposed skeletal surfaces, and they are continuing to advance across the colony, slowly overgrowing remaining tissue. There has also been patchy recruitment of scleractinian corals onto reef substrata and dead coral skeletons, especially Agaricia, Porites, Diploria, Eusmilia, Meandrina, Siderastrea, and M. cavernosa. Over the duration of the study, however, no recruits of $M$. annularis (complex) were identified (Fig. 9).

\section{DISCUSSION}

Coral reefs throughout the western Atlantic have been dramatically altered over the past 3 decades. Localized human impacts, such as overfishing, pollution, and sed-

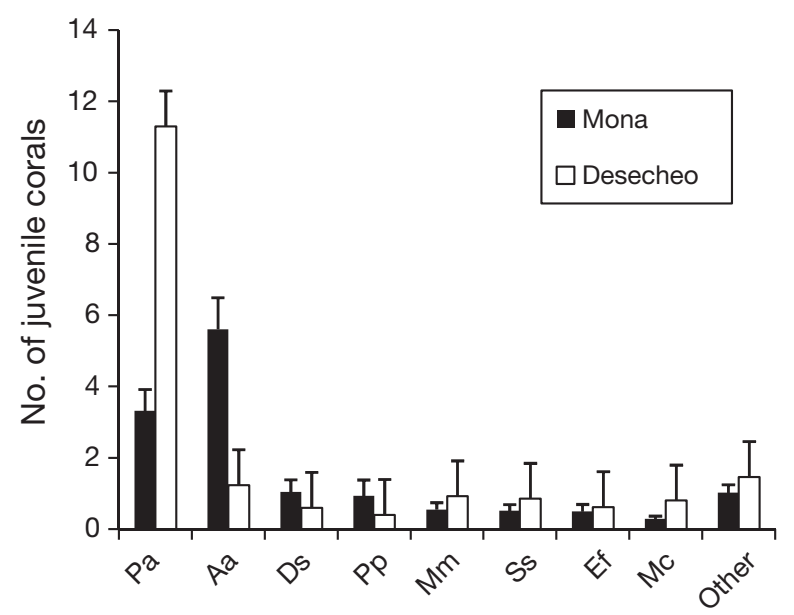

Fig. 9. Mean number of juvenile corals per square meter for Mona (black bars) and Desecheo (white bars). The standard error reflects the variation between sites. Coral taxon abbreviations as in Figs. 2 \& 8 imentation, are considered the primary factors responsible for coral losses off populated islands, and there is growing evidence that these stressors may exacerbate the occurrence, virulence, and effects of natural stressors such as disease and bleaching (Harvell et al. 2002). Declines in coral abundances and cover have been well documented in nearshore locations, but less research has been conducted on remote, deepwater, and offshore reefs. This study provides evidence that coral diseases and bleaching can be major factors responsible for coral losses in remote locations, even in the absence of most direct and indirect human influences.

On reefs off Mona Island and Desecheo Island, unprecedented coral losses of some of the most hardy, long-lived species were documented over the last decade (Bruckner \& Bruckner 2006a). Many of the more sensitive species (e.g. acroporids) have shown increasing trends of decline off Mona Island, primarily due to white band disease, increased corallivory, and hurricane effects (Bruckner \& Bruckner 2006c), but these species could recover fairly quickly through rapid growth rates and propagation through fragmentation. The rapid and near complete loss of Montastraea annularis (complex) at these sites is of much greater concern, at least in ecological time frames, as these corals are much older and slower growing, and they appear to be less resilient to potential future changes. In particular, these corals appear to be highly vulnerable to climate change, especially effects of bleaching and several newly emergent and highly virulent coral diseases.

YBD has become particularly insidious, with outbreaks affecting 18 to $91 \%$ of the Montastraea colonies in reefs throughout the western Atlantic, including sites in Panama, the Netherland Antilles, Colombia, Mexico, Puerto Rico, Venezuela, and other locations (Santavy et al. 1999, Cervino et al. 2001, Bruckner \& Bruckner 2003, 2006b, Gil-Agudelo et al. 2004, JordánDahlgren \& Rodríguez-Martínez 2004, Weil \& Cróquer 2009). On reefs off Mona Island, YBD was the most prevalent disease, and it caused more tissue loss to Montastraea annularis (complex) than any other factor (Bruckner \& Bruckner 2006a). Even though rates of mortality were very slow $\left(<1 \mathrm{~cm} \mathrm{mo}^{-1}\right)$, affected colonies experienced slow, progressive mortality from YBD for up to a decade, until the colony died. WP was also locally important, causing an unusually rapid rate of tissue loss (up to 1-10 $\mathrm{cm} \mathrm{d}^{-1}$ ), and affecting a high number of species, especially during outbreaks observed in 1998-1999 and 2005. In addition to YBD and WP, $M$. annularis (complex) is reported to be susceptible to at least 4 other diseases (Weil 2004, Weil \& Cróquer 2009), and in this study, individual colonies were observed with YBD, WP, BBD, and dark spots disease at the same time. While colonies showed a slow pro- 
gressive decline from disease (Bruckner \& Bruckner 2006a), losses accelerated during and immediately following the 2005 bleaching event, with extensive bleaching-associated tissue loss and a reemergence of several diseases, similar to that observed in other sites off Puerto Rico and the USVI (Miller et al. 2006, Ballantine et al. 2008, Rogers et al. 2008).

The modular life form and the ability for colonies to survive with partial mortality has been suggested to provide Montastraea annularis (complex) with the ability to respond rapidly to environmental and human disturbances. The high densities of large colonies of $M$. annularis (complex) observed throughout the Caribbean suggest that, at least until recently, these species were less susceptible to the stressors that contributed to the demise of other species, including physical disturbance, bleaching, disease, and predation (Bythell et al. 1993). These corals are reported to be extremely robust and resistant to the effects of all but the most severe storms and hurricanes (Stoddart 1963, Woodley et al. 1981, Bythell et al. 2000). Even though columnar lobate $M$. annularis colonies are frequently fragmented during storms, damaged colonies exhibit high rates of healing and survival when compared to other corals (Bak \& Engel 1979). Their greater surface area may also make them more vulnerable to disturbance and damage, yet the capacity for regeneration is positively correlated with increasing body size (Bythell et al. 1993, Meesters et al. 1996, Bak \& Meesters 1998), which may be a reason why these corals were historically able to achieve and maintain an unusually large colony size. Nevertheless, the ability to resheet is dependent on the size of the lesion, and it may be prevented if other competitors settle on exposed skeletal surfaces or other stressors compromise tissue isolates. In this study, remnant patches of tissue failed to spread over denuded colony surfaces, and tissue isolates continue to shrink in size as a result of post-bleaching mortality and disease outbreaks, damselfish algal lawns, overgrowth by clionid sponges and other invertebrates, and colonization of adjacent skeletal surfaces by dense mats of macroalgae and cyanobacteria. The exposed skeletal surfaces of these corals have also been colonized by crustose coralline algae, and many important reef-building genera have recruited onto dead coral, including Eusmilia, Porites, Agaricia, Diploria, and Colphophyllia, but not M. annularis (complex).

The main influences to these reefs over the duration of the study included coral disease outbreaks and mass bleaching events. These stressors are resulting in the progressive elimination of Montastraea annularis (complex), the dominant long-lived broadcast spawners that have been historically considered the most important structural framework corals. The unusually fast spreading rates of WP, along with an unusually long, but slow sustained tissue loss from YBD, appear to be causing impaired skeletal growth and diminished reproductive output (Bruckner \& Bruckner 2006a, Weil et al. 2006). Continued tissue loss and fission may further reduce the reproductive potential of these colonies as the colony diverts more energy to maintenance, increasing the proportion of small, non-breeding colonies in the population. Disease outbreaks and bleaching events are expected to continue to increase under varying scenarios of climate change (Harvell et al. 2002, McClanahan et al. 2002), and unless factors and processes that enhance the resilience of reefs to climate change, it is likely that these corals will continue their decline, and they may be replaced by other species, including non-reef-building organisms. While the physical structure provided by $M$. annularis (complex) may remain intact for many decades, denuded colony surfaces, especially off Mona Island, are being rapidly colonized by bioeroding sponges (e.g. Cliona spp.) which is speeding up the dissolution and breakdown of the reef framework. Concurrently, there is an increase in juvenile corals of other species, and existing colonies of these species are being less affected by current influences (disease and bleaching), suggesting that they may be more resilient. Some of the long-term consequences of this could include a permanent change towards reefs with lower topographic relief and reduced rates of accretion, along with a shift from long-lived massive corals to a dominance by shortlived submassive, branching and plating corals and other non-reef-building early colonizers including gorgonians, colonial anemones, and fleshy algae.

Acknowledgements. Support for this project was provided by the NOAA Coral Reef Conservation Program (2003-2008), Earthwatch (1999-2001), University of Puerto Rico (UPR) Department of Marine Sciences, and NOAA Fisheries Office of Habitat Conservation. We are grateful for the in-water assistance provided by R. Bruckner, E. Borneman, M. Scharer, M. Nemeth, K. Kilfoyle, and numerous UPR graduate students and Earthwatch volunteers. Special thanks to P. Garcia and Mona Aquatics for logistical support and the Department of Natural and Environmental Resources (DNER) for assistance with lodging and other needs while on Mona Island. Three anonymous reviewers provided detailed comments that greatly improved this manuscript. Research was conducted under permits from the Puerto Rico DNER (07-1C-009).

\section{LITERATURE CITED}

Aronson RB, Precht WF (2001) White-band disease and the changing face of Caribbean coral reefs. Hydrobiologia 460:25-38

Aronson RB, MacIntyre IG, Precht WF, Murdoch TJT, Wapnick CN (2002) The expanding scale of turnover events on coral reefs in Belize. Ecol Monogr 72:233-249

> Bak RPM, Engel MS (1979) Distribution, abundance and survival of juvenile hermatypic corals (Scleractinia) and the 
importance of life history strategies in the parent coral community. Mar Biol 54:341-352

Bak RPM, Meesters EH (1998) Coral population structure: the hidden information of colony size-frequency distributions. Mar Ecol Prog Ser 162:301-306

Ballantine DL, Appeldoorn RS, Yoshioka P, Weil E and others (2008) Biology and ecology of Puerto Rican coral reefs. In: Reigl BM, Dodge RE (eds) Coral reefs of the world. 1. Coral reefs of the USA. Springer, Berlin, p 375-406

Bruckner AW (2003) Proceedings of the Caribbean Acropora workshop: potential application of the Endangered Species Act as a conservation strategy. NOAA Tech Memo NMFS-OPR-24, Silver Spring, MD

Bruckner AW, Bruckner RJ (2003) Coral predation by Sparisoma viride and lack of relationship with coral disease. Proc 9th Int Coral Reef Symp Bali 2:1245-1250

Bruckner AW, Bruckner RJ (2006a) Consequences of yellow band disease (YBD) on Montastraea annularis (species complex) populations on remote reefs off Mona Island, Puerto Rico. Dis Aquat Org 69:67-73

Bruckner AW, Bruckner RJ (2006b) The recent decline of Montastraea annularis (complex) coral populations in western Curacao: a cause for concern? Rev Biol Trop 54: 45-58

Bruckner AW, Bruckner RJ (2006c) Restoration outcomes of the Fortuna Reefer Grounding at Mona Island, Puerto Rico. In: Precht WF (ed) Coral reef restoration handbook - the rehabilitation of an ecosystem under siege. CRC Press, Boca Raton, FL, p 257-270

Bythell JC, Gladfelter E, Bythell M (1993) Chronic and catastrophic natural mortality of three common Caribbean corals. Coral Reefs 12:143-152

Bythell JC, Hillis-Starr ZM, Rogers CS (2000) Local variability but landscape stability in coral reef communities following repeated hurricane impacts. Mar Ecol Prog Ser 204: 93-100

Carpenter RC (1990) Mass mortality of Diadema antillarum. I. Long-term effects on sea urchin population dynamics and coral reef algal communities. Mar Biol 104:67-77

Cervino J, Goreau TJ, Nagelkerken I, Smith GW, Hayes R (2001) Yellow band and dark spot syndromes in Caribbean corals: distribution rate of spread cytology and effects on abundance and division rate of zooxanthellae. Hydrobiologia 460:53-63

Edmunds PJ, Carpenter RC (2001) Recovery of Diadema antillarum reduces macroalgal cover and increases the abundance of juvenile corals on a Caribbean reef. Proc Natl Acad Sci USA 98:5067-5071

Edmunds PJ, Elahi R (2007) The demographics of a 15-year decline in cover of the Caribbean reef coral Montastraea annularis. Ecol Monogr 77:3-18

Gil-Agudelo DL, Smith GW, Garzón-Ferreira J, Weil E, Peterson D (2004) Dark spots disease and yellow band disease, two poorly known coral diseases with high incidence in Caribbean reefs. In: Rosenberg E, Loya Y (eds) Coral health and disease. Springer, Berlin, p 337-350

Gladfelter EH, Monahan RK, Gladfelter WB (1978) Growth rates of five reef-building corals in the northeastern Caribbean. Bull Mar Sci 28:728-734

Goreau TF (1959) The ecology of Jamaican coral reefs. I. Species composition and zonation. Ecology 40:67-90

$>$ Green EP, Bruckner AW (2000) The significance of coral disease epizootiology for coral reef conservation. Biol Conserv 96:347-361

> Harvell CD, Mitchell CE, Ward JR, Altizer S, Dobson AP, Ostfeld RS, Samuel MD (2002) Climate warming and disease risks for terrestrial and marine biota. Science 296: 2158-2162
Hughes TP (1984) Population dynamics based on individual size rather than age: a general model with a reef coral example. Am Nat 123:778-795

Hughes TP (1990) Recruitment limitation, mortality, and population regulation in open systems: a case study. Ecology 71:12-20

> Hughes TP (1994) Catastrophes, phase shifts, and large scale degradation of a Caribbean reef. Science 265:1547-1551

Hughes TP, Tanner JE (2000) Recruitment failure, life histories, and long term decline of Caribbean corals. Ecology 81:2250-2263

Jackson JBC (1992) Pleistocene perspectives on coral reef community structure. Am Zool 32:719-731

Johnson KG, Budd AF, Stemann TA (1995) Extinction selectivity and ecology of Neogene Caribbean corals. Paleobiology 21:52-73

Jordán-Dahlgren E, Rodríguez-Martínez RE (2004) Coral diseases in Gulf of Mexico reefs. In: Rosenberg E, Loya Y (eds) Coral health and disease. Springer, Berlin, p 105-118

Knowlton N (1992) Thresholds and multiple stable states in coral reef community dynamics. Am Zool 32:674-682

Kramer PR, Lang JC (2003) The Atlantic and Gulf Rapid Reef Assessment (AGRRA) protocols: former version 2.2. In Lang JC (ed) Status of coral reefs in the western Atlantic: results of initial surveys, Atlantic and Gulf Rapid Reef Assessment (AGRRA) Program. Atoll Res Bull 496: 611-624

Lessios HA (1988) Mass mortality of Diadema antillarum in the Caribbean: What have we learned? Annu Rev Ecol Syst 19:371-393

McClanahan T, Polunin N, Done T (2002) Ecological states and the resilience of coral reefs. Conserv Ecol 6:18

Meesters EH, Wesseling I, Bak RPM (1996) Partial mortality in three species of reef-building corals and the relation with colony morphology. Bull Mar Sci 58:838-852

Miller J, Waara R, Muller E, Rogers C (2006) Coral bleaching and disease combine to cause extensive mortality on reefs of the US Virgin Islands. Coral Reefs 25:418

Raymundo LJ, Couch CS, Bruckner AW, Harvell CD and others (2008) Coral disease handbook. Guidelines for assessment, monitoring and management. Curie Communications, Melbourne

Richardson L, Goldberg W, Kuta K, Aronson R and others (1998) Florida's mystery coral killer explained. Nature 392: 557-558

Rogers CS, Miller J, Muller E, Edmunds PJ and others (2008) Ecology of coral reefs in the US Virgin Islands. In: Reigl BM, Dodge RE (eds) Coral reefs of the world. 1. Coral reefs of the USA. Springer, Berlin, p 303-374

Santavy DL, Peters EC, Quirolo C, Porter JW, Bianchi CN (1999) Yellow-blotch disease outbreak on reefs of the San Blas Islands, Panama. Coral Reefs 18:97

Stoddart DR (1963) Effects of Hurricane Hattie on the British Honduras reefs and cays, October 30-31, 1961. Atoll Res Bull 95:1-142

Sutherland KP, Porter JW, Torres C (2004) Disease and immunity in Caribbean and Indo-Pacific zooxanthellate corals. Mar Ecol Prog Ser 266:273-302

Szmant AM (1991) Sexual reproduction by the Caribbean reef corals Montastraea annularis and M. cavernosa. Mar Ecol Prog Ser 74:13-25

Szmant-Froelich AM (1985) The effect of colony size on the reproductive ability of the Caribbean coral Montastraea annularis (Ellis and Solander). Proc 5th Int Coral Reef Symp Tahiti 4:295-300

Weil E (2004) Coral reef diseases in the wider Caribbean. In: 
Rosenberg E, Loya Y (eds) Coral health and disease. Springer, Berlin, p 35-68

Weil E, Cróquer A (2009) Spatial variability in distribution and prevalence of Caribbean scleractinian coral and octocoral diseases. I. Community-level analysis. Dis Aquat Org 83:195-208

Editorial responsibility: Kiho Kim, Washington, DC, USA
Weil E, Smith G, Gil-Agudelo DL (2006) Status and progress in coral reef disease research. Dis Aquat Org 69: $1-7$

> Woodley JD, Chornesky EA, Clifford PA, Jackson JBC and others (1981) Hurricane Allen's impact on Jamaican coral reefs. Science 214:749-755

Submitted: January 6, 2009; Accepted: July 22, 2009

Proofs received from author(s): October 13, 2009 